\title{
Oxygen as a facilitator in the reduction of surgical site infections
}

\author{
A Arsalan ${ }^{1}$, M Alam $^{2}$, S B S Naqvi ${ }^{3}$, I Ahmad ${ }^{1}$, Z Anwar \\ ${ }^{1}$ Institute of Pharmaceutical Sciences, Baqai Medical University, \\ ${ }^{2}$ Department of Biochemistry, Dow University of Health Sciences \\ ${ }^{3}$ Department of Pharmaceutics, Faculty of Pharmacy, University of Karachi, \\ Karachi, Pakistan
}

Key words: ; Atelectasis; oxidative killing; tissue oxygenation; immune system; phagocytosis

\section{Introduction}

Surgical site infections (SSIs) are the most common nosocomial infection globally. According to the Centre for Disease Control (CDC), approximately 27 million operations are performed annually in the USA. SSI is the major cause of morbidity and mortality and is mainly associated with overstay in hospitals and an increase in expenditure. Coello and his colleagues estimated that extra stay in hospital increases 11.4 days with an extra expenditure of $£ 3,500$ [1]. Thus, it is important to reduce or prevent SSI by revisiting measures such as transfusion of blood, shaving, hypovolaemia, hypothermia, hyperglycemia, malnutrition, oxygen supply, pre-operative stay, use of aseptic and antiseptic concepts such as the ultra clean room, the duration and technique of operation [2].

\section{Supplemental oxygen}

The WHO recommends appropriate supply of oxygen according to the need of the patient during operation [4]. It has been found that a high fraction of inspired oxygen has advantages like reduction in the frequency of postoperative nausea and vomiting [5,6], healing of colorectal anastomoses [7] and reduction in the rate of SSI [8]. Furthermore, hyperoxia may help in the prevention of pneumonia [9].

\section{Risk associated with supplemental oxygen}

Pulmonary defence mechanisms may be weakened by supplemental oxygen or mechanical ventilation [10]. Supplemental oxygen might lead to insufficient regulation of blood glucose levels [11], and it may alter the cardiac index [12]. Hyperoxia has been related to unfavourable effects such as an increased

Correspondence : Arsalan A

Email : adeelarsalan@hotmail.com risk of airway irritation [13]. During prolonged use, it may lead to pulmonary inflammation and atelectasis $[10,14]$. These authors found that a high level of inspired oxygen might lead to respiratory complications like pulmonary atelectasis that can be identified by computed tomography (CT). Large areas of atelectasis are caused by exposure to air for 5 minutes with 100 percent oxygen as compared to ventilation with lower oxygen concentration [15]. By contrast, oxygen administered in a concentration of 80 percent has not been reported to result in the side effects reported with administration of 100 percent oxygen [16]. Pulmonary atelectasis is mainly caused by short periods of oxygen administration [17].

\section{Anaesthesia, tissue oxygenation and hypoxia}

\section{Tissue oxygenation}

Tissue oxygenation is dependent on circulating haemoglobin in tissues, the level of oxygen in plasma and tissue blood flow [18]. The oxygen partial pressure in tissue is enhanced by perioperative supplemental oxygen administration. Although oxygenated arterial blood is fully saturated in a patient, the partial pressure of oxygen may vary in subcutaneous tissues. Oxidative killing helps in the reduction of SSI by increasing the oxygen tension in the tissues [19]. In turn, tissue oxygenation is dependent on factors such as smoking, fluid management, temperature, anaemia, and postoperative pain [20]. The level of oxygenation in tissues is often low in wounds and colorectal anastomoses. This reduces tissue healing by oxidative killing and also decreases neovascularization, epithelialization and initiation of collagen formation [21, 22, 23].

\section{Hypoxia}

Hypoxia is one of the most dreadful conditions that anaesthetists have to deal with. For general anaesthesia, supplemental oxygen is necessary to ensure the proper supply of oxygen and the prevention 
of hypoxia. It has been found that analgaesics and anaesthesia influence respiratory function and this may lead to hypoxia which may produce persistent effects for up to five days, especially at night [24].

\section{Reasons for hypoxia}

Neuromuscular blocking agents such as benzodiazepines and opioids suppress ventilation. Prolonged surgery and re-operation is associated with blood loss which may cause hypoxia [25]. Oxygen delivery to tissues is impaired by coronary artery disease and obstructive pulmonary disease which may reduce oxidative killing [26]. Myocardial ischaemia, thrombosis and vascular surgery reduce oxygen tension in tissues and may lead to hypoxia [27]. Often, surgery results in hypoxia caused by weakening of ventilatory and gas exchange.

\section{Body mass index}

If the body mass index (BMI) is $35 \mathrm{~kg} / \mathrm{m}^{2}$ it increases the chance of SSIs because of the impaired oxygen supply to poorly vascularised adipose tissue and reduced immunity. Obesity decreases circulation leading to tissue hypoxia [19]. Pryor and colleagues found that if the BMI exceeded $30 \mathrm{~kg} / \mathrm{m}^{2}$ patients required increased oxygen supplementation [28].

\section{Smoking}

Several studies found that smoking increased SSIs $[29,30,31]$. Smoking causes vasoconstriction and reduces tissue oxygenation. Gravante and co-workers found that the risk of SSIs was reduced by $37 \%$ in nonsmokers compared with smokers [31].

\section{Oxidative killing}

Pathogenic bacteria can be eradicated by oxidative killing. Oxidative killing helps in the reduction of SSI by increasing the oxygen tension in the tissues - It facilitates healing of wounds by epithelialization, decreases initiation of collagen formation and neovascularization [23]. Oxidative killing enhances the immune defense system by production of superoxide radicals from oxygen by NADPH linked oxygenase which acts as a catalyst [22, 32]. Furthermore, lysyl and prolyl hydroxylase are catalyzed by oxygen, which helps in the hydroxylation of lysine and proline respectively [33].

\section{Mechanism of oxidative killing}

Oxidative killing results from the production of bactericidal superoxide radicals from oxygen. The unstable oxygen intermediates and hydrogen peroxide boost the phagocytic activity of neutrophils [32]. Oxidative pathway inhibitors like cyanide and hypoxia greatly impair killing of ingested organisms [34]. Vascular endothelial growth factor is activated by oxygen free radicals and peripheral vasoconstriction is caused by hypoxia which impairs cardiac function [ 35 , 36]. Neutrophils need glucose for energy and molecular oxygen for the production of the bactericidal free radicals of oxygen and hydrogen peroxide [35]. The energy production by glucose and oxygen intermediate free radicals is hampered by some bacteria.

\section{The role of the immune system}

Polymorphonuclear leukocytes help in the reduction of the bacterial count due to oxidative killing. Thus, high amounts of oxygen for shorter periods of time effectively decrease bacterial count and reduce the size of lesions. Silver et al found that oxygen is consumed by phagocytes in an area of infection [36]. Mandell et al reported that in anaerobic conditions some bacteria are efficiently killed by phagocytosis but others may not be killed [37]. Knighton et al. observed that the wound size reduced by $36 \%$ when it was exposed to oxygen at either a concentration of $45 \%$ for 1.5 hours or $12 \%$ for 46.5 hours respectively [38].

\section{Phagocytosis}

Environmental oxygen plays a vital role in infection. Phagocytes utilized oxygen in reduction of tissue oedema and the eventual occlusion of the microvasculature. During phagocytosis, neutrophils are activated by a number of metabolic reactions with a rise in oxygen utilization [39]. Furthermore, activated neutrophils increase oxygen consumption resulting in lower tissue oxygenation and also cause cell injury by hydrogen peroxide, superoxide anions and hydroxyl radicals which may be lethal [38].

\section{Tissue partial pressure $\left(\mathrm{Po}_{2}\right)$ / fraction of inspired oxygen $\left(\mathrm{FiO}_{2}\right)$}

Tissue partial pressure $\left(\mathrm{PO}_{2}\right)$ is mainly dependent upon sufficient oxygenation of blood. Hohn et al. found that if the level of oxygen was raised to $5 \mathrm{mmHg}$, the killing rate was $58 \%$ while if it was increased to $30 \mathrm{mmHg}$ the 
bactericidal activity was 70\% [5]. Oxygen enhances the activity of leukocytes to kill microbes. Also, it has been observed that the rate of SSIs decreases if the fraction of inspired oxygen is high $[5,8]$. If the $\mathrm{FiO}_{2}$ is $45 \%$, the tissue $\mathrm{PO}_{2}$ is $40 \mathrm{~mm} \mathrm{Hg}$ but if the $\mathrm{FiO}_{2}$ falls to $20 \%$ the $\mathrm{PO}_{2}$ may reduce to $20 \mathrm{~mm} \mathrm{Hg}$. This reduction may cause small changes in blood oxygen content but large changes in tissue oxygenation. Tissue $\mathrm{PO}_{2}$ is low in infected tissue and supplemental oxygen by increasing $\mathrm{FiO}_{2}$ levels helps prevent weakening of neutrophil killing, tissue necrosis and inhibits proliferation of bacteria and death of local tissues. Administration of antibiotics with increased levels of $\mathrm{FiO}_{2}$ results in efficient bactericidal activity.

In conclusion, oxygen acts as a facilitator in the reduction of surgical site infections particularly in colorectal and abdominal surgery. Supplemental oxygen aids in the eradication of pathogenic bacteria by oxidative killing. Not only does oxidative killing heal wounds, it also enhances the activity of the immune system by forming superoxide radicals. Furthermore, polymorphonuclear leukocytes also participate in the eradication of bacteria by oxidative killing. While free radicals of oxygen activate vascular endothelial growth and help in vasoconstriction, hypoxia is a major detrimental factor in the occurence of SSIs.

\section{References}

1. Coello R, Charlett A, Wilson J, Ward V, Pearson A, and Borriello P. Adverse impact of surgical site infections in English hospitals. J. Hosp. Infect. 2005; 60: 93-103.

2. Mangram AJ, Horan TC, and Pearson ML. Guideline for prevention of surgical site infection. Infect. Control Hosp. Epidemiol. 1999; 20(4):250278.

3. Rabkin J M, and Hunt TK. Local heat increases blood flow and oxygen tension in wounds. Arch. Surg., 1987; 122: 221-225.

4. WHO Guidelines for Safe Surgery (2009). World Health Organization, Geneva.

5. Greif R, Akca O, Horn EP, Kurz A, and Sessler DI. Supplemental perioperative oxygen to reduce the incidence of surgical-wound infection. Outcomes Research Group. N. Engl. J. Med., 2000; 342:161167.
6. Turan A, Apfel CC, Kumpch M, Danzeisen O, Eberhart LH, Forst H, Heringhaus C, Isselhorst C, Trenkler S, Trick M, Vedder I, and Kerger H. Does the efficacy of supplemental oxygen for the prevention of postoperative nausea and vomiting depend on the measured outcome, observational period or site of surgery? Anaesthesia. 2006; 61(7):628-633.

7. Garcia-Botello SA, Garcia Granero E, Lillo R, Lopez-Mozos F, Millan M, and Lledo S. Randomized clinical trial to evaluate the effects of perioperative supplemental oxygen administration on the colorectal anastomosis. $\mathrm{Br}$. J. Surg. 2006; 93(6): 698-706.

8. Belda FJ, Aguilera L, Garcia de la Asuncion J, Alberti J, Vicente R, Ferrandiz L, Rodriguez R, Company R, Sessler DI, Aguilar G, Botello SG, Orti R; Spanish Reduccion de la Tasa de Infeccion Quirurgica Group. Supplemental perioperative oxygen and the risk of surgical wound infection: a randomized controlled trial. J. Am. Med. Assoc., 2005; 294: 2035-2042.

9. Hohn DC, MacKay RD, Halliday B, and Hunt TK. Effect of $\mathrm{O} 2$ tension on microbicidal function of leukocytes in wounds and in vitro. Surg. Forum 1976; 27: 18-20.

10. Kotani N, Hashimoto H, Sessler DI, Muraoka M, Wang JS, O Connor MF, and Matsuki A. Cardiopulmonary bypass produces greater pulmonary than systemic proinflammatory cytokines. Anesth. Analg. 2000; 90 (5): 10391045.

11. Bandali KS, Belanger MP, and Wittnich C. Does hyperoxia affect glucose regulation and transport in the newborn? J. Thorac. Cardiovasc. Surg., $2003 ; 126$ (6): 1730-1735.

12. Carpagnano GE, Kharitonov SA, FoschinoBarbaro MP, Resta O, Gramiccioni E, and Barnes PJ. Supplementary oxygen in healthy subjects and those with COPD increases oxidative stress and airway inflammation. Thorax 2004; 59(12): 10161019.

13. Harten JM, Anderson KJ, Angerson WJ, Booth MG, and Kinsella J. The effect of normobaric hyperoxia on cardiac index in healthy awake volunteers. Anaesthesia 2003; 58 (9): 885-888. 
14. Akca O, Podolsky A, Eisenhuber E, Panzer O, Hetz H, Lampl K, Lackner FX, Wittmann K, Grabenwoeger F, Kurz A, Schultz AM, Negishi C, and Sessler DI. Comparable postoperative pulmonary atelectasis in patients given $30 \%$ or $80 \%$ oxygen during and 2 hours after colon resection. Anesthesiology. 1999: 91 (4): 991-998.

15. Edmark L, Kostova-Aherdan K, Enlund M, and Hedenstierna G. Optimal oxygen concentration during induction of general anesthesia. Anesthesiology 2003; 98 (1):28-33.

16. Rothen HU, Sporre B, Engberg G, Wegenius G, Reber A, and Hedenstierna G. Prevention of atelectasis during general anaesthesia. Lancet, 1995; 345: 1387-1391.

17. Lindberg P, Gunnarsson L, Tokics L, Secher E, Lundquist $\mathrm{H}$, Brismar $\mathrm{B}$, and Hedenstierna $\mathrm{G}$. Atelectasis and lung function in the postoperative period. Acta Anaesthesiol. Scand. 1992; 36 (6): 546-553.

18. NICE Surgical Site Infection Prevention and Treatment of Surgical Site Infection. National Institute for Health and Clinical Excellence, London, 2008.

19. Hopf HW, Hunt TK, West JM, Blomquist $P$, Goodson WH 3rd, Jensen JA, Jonsson K, Paty PB, Rabkin JM, Upton RA, von Smitten K, Whitney JD. Wound tissue oxygen tension predicts the risk of wound infection in surgical patients. Arch. Surg.1997; 132: 997-1004.

20. Sessler DI Non-pharmacological prevention of surgical wound infection. Anesthesiol. Clin., 2006; 24 (2): 279-297.

21. Niinikoski J, Jussila P, and Vihersaari T. Radical mastectomy wound as a model for studies of human wound metabolism. Am. J. Surg., 1973; 126(1):53- 58 .

22. Babior BM. Oxygen-dependent microbial killing by phagocytes. N. Engl. J. Med., 1978; 298: 659668.

23. Hopf HW, and Holm J. Hyperoxia and infection. Best Pract Res Clin Anaesthesiol. 2008; 22 (3): 553-569.
24. Wilkinson IB, Webb Christison DJ, and Cockroft JR. Isolated systolic hypertension: a radical rethink. It's a risk factor that needs treatment, especially in the over 50s. Br. Med. J. 2000; 320 (7251): 1685.

25. Haridas M and Malangoni MA. Predictive factor for surgical site infection in general surgery. Surgery 2008; 144 (4): 496-503.

26. Henry G, and Garner WL. Inflammatory mediators in wound healing. Surg. Clin. North Am., 2003; 83: 483-507.

27. Gill NP, Wright B, and Reilly CS. Relationship between hypoxaemia and cardiac ischaemic events in the perioperative period. Br. J. Anaesth., 1992; 68 (5): 471-473.

28. Pryor KO, Fahey TJ 3rd, Lien CA, and Goldstein PA. Surgical site infection and the routine use of perioperative hyperoxia in a general surgical population: A randomized controlled trial. J. Am. Med.Assoc., 2004;291:79-87

29. Ridderstolpe L, Gill H, Granfeldt $H$, Ahlfeldt $H$, Rutberg H. Superficial and deep sternal wound complications: Incidence, risk factors and mortality. Eur J Cardiothorac Surg., 2001; 20: 1168-1175.

30. Neumayer L, Hosokawa P, Itani K, El-Tamer M, Henderson WG, Khuri SF. Multivariable predictors of postoperative surgical site infection after general and vascular surgery: results from the patient safety in surgery study. J. Am. Coll. Surg. 2007; 204: 1178-1187.

31. Gravante G, Araco A, Sorge R, Caruso R, Nicoli F, Araco F, Delogu D, Cervelli V. Postoperative wound infections after breast reductions: The role of smoking and the amount of tissue removed. Aesthetic Plast. Surg., 2008 ;32:25-31.

32. Allen DB, Maguire JJ, Mahdavian M, Wicke C, Marcocci L, Scheuenstuhl H, Chang M, Le AX, Hopf HW, Hunt TK. Wound hypoxia and acidosis limit neutrophil bacterial killing mechansims. Arch. Surg. 1997; 132: 991-996.

33. Prockop DJ, Kivirikko KI, Tuderman L, and Guzman NA. The biosynthesis of collagen and its disorders: Part one. N. Engl. J. Med., 1979; 301: 
13-23.

34. Cheson B, Curnutte J, and Babior B. The oxidative killing mechanisms of the neutrophil, in Schwartz RS (Ed): Progress in Clinical Immunology., Grune \& Stratton, New York 1977.

35. Hohn D. Leukocyte phagocytic function and dysfunction. Surg. Gynecol. Obstet. 2007; 144: 99-104.

36. Silver I. Tissue Po 2 changes in acute inflammation. Adv. Exp. Med. Biol., 1978; 94: 769-774.

37.Mandell G. Bactericidal activity of aerobic and anaerobic polymorphonuclear neutrophils. Infect. Immun. 1974; 9: 337-341.

38. Knighton DR, Halliday B, Hunt TK. Oxygen as an antibiotic. A comparison of the effects of inspired oxygen concentration and antibiotic administration on in vivo bacterial clearance. Arch Surg. 1986; 121(2):191-5.

39. Klebanoff S. Oxygen metabolism and the toxic properties of phagocytes. Ann. Intern. Med., 1980; 93:480-489. 